\title{
Strategi Perbankan Syariah dalam Menanggulangi Potensi Kerugian pada Akad Mudhrabah
}

\author{
Sofian Syaiful Rizal \\ Universitas Nurul Jadid \\ Sofiansyaifulrizal@gmail.com \\ Nuri Ma'rifatul Laily \\ Universitas Nurul Jadid \\ nurimarifatullaily@gmail.com
}

\begin{abstract}
Abstrak Bank dalam memberikan pembiayaan kepada nasabah tidak bisa terlepas dari risiko pembiayaan salah satunya adalah pembiayaan bermasalah yang dapat memicu terjadinya potensi kerugian pada bank. Penelitian ini bertujuan untuk menanggulangi terjadinya potensi kerugian pada akad mudharabah. Mengingat tingginya risiko pembiayaan bermasalah pada akad mudharabah. Penelitian ini menggunakan jenis pendekatan library research kualitatif deskriptif. Teknik pengambilan data menggunakan teknik analisis referensional, dan melakukan wawancara. Adapun kesimpulannya selektivitas dalam pemilihan calon nasabah dengan melakukan pengenalan nasabah yakni melalui penilaian karakter menggunakan prinsip $5 \mathrm{C}+1 \mathrm{~S}$; Character, Capacity, Capital,Collateral, Condition of Economic dan Syariah dan melakukan monitoring pasca-nasabah dengan adanya pemantauan lapangan atau melakukan silaturrahmi kepada rumah atau tempat usaha nasabah guna memilimalisir terjadinya risiko pembiayaan. Adapun pemilihan strategi dalam menanggulangi potensi kerugian pembiayaan yakni dengan penggunaan strategi yang tepat dan akurat sesuai tingkat kolektibilitas pembiyaannya. Strategi yang bisa digunakan secara garis besar dikelompokkan menjadi dua: pertama stay strategi dengan melakukan restrukturisasi pembiayaan (rescheduling, restructuring, reconditioning), kedua phease out strategy, strategi ini dilakukan menggunakan dua pendekatan yakni soft approach penyelesaiaan pembiayaan diluar pengadilan dan hard approah penyelesaian pembiayaan dengan cara melibatkan jalur hukum.
\end{abstract}

Kata Kunci Strategi Perbankan, Potensi Kerugian, Mudharabah

\section{PENDAHULUAN}

Indonesia merupakan suatu negara yang mayoritas penduduknya beragama islam dan sudah lama mengharapkan hadirnya sistem ekonomi yang berpegang teguh terhadap nilai-nilai syariat islam. Terutama yang berkaitan dengan lembaga keuangan bank yang identik dengan adanya bunga (riba) disetiap transaksinya. Dalam syariat islam, adanya bunga (riba) diharamkan dalam setiap transaksi ekonomi, karena akan menimbulkan kemudaratan seperti adanya salah satu pihak yang akan dirugikan, sedangkan dalam agama islam lebih mengutamakan adanya sebuah kemaslahatan. 
Pendirian Bank Syariah medahului penetapan peraturannya adalah sesuatu yang unik, karena tidak didukung oleh aturan khusus mengenai perbankan syariah sebagai payung hukum. Pendirian Bank Syariah didirikan tahun 1991 sedangkan aturan tentang bagi hasil ditetapkan tahun 1992. Keunikan bank ini terdapat pada sistem yang menjadi landasa operasional bank, yaitu sistem bagi bagi hasil keuntungan dan kerugian (loss and profit sharing), mengeyampingkan sistem bunga (interest). Bank-bank yang ada pada saat itu mengacu kepada Undang-undang Nomor 14 Tahun 1967 tentang Pokok-Pokok Perbankan, yang menyatakan semuan bank dalam menjalankan kegiatan usahanya menganut sistem bunga (Arifin, 2018).

Salah satu risiko pembiayaan ialah terjadinya pembiayaan bermasalah. Pembiayaan bermasalah akan menyebabkan pendapatan suatu perusahaan atau bank menurun, bahkan bisa menyebabkan suatu kerugian. Seperti halnya yang terjadi pada Bank Muamalat Indonesia pada laporan keuangan periode I 2019 yang hanya mampu mengantongi laba bersih sebesar RP 5,08 miliar sepanjang paruh pertama 2019. Capaian itu anjlok 95\% dibanding periode yang sama tahun 2018 yang sebesar RP 103,7 miliar. Anjloknya perolehan laba bersih itu, disebabkan turunnya pendapatan penyaluran dana, melambatnya pembiyaan mudharabah dan musyarakah, dan meningkatnya rasio non performing financing (NPF). Per juni 2019, NPF gross Bank Muamalat membengkak menjadi $5,41 \%$ dari $1,65 \%$ pada Juni 2018 . NPF net juga naik tajam dari $0,88 \%$ menjadi 4,53 atau telah mendekati ambang batas normal sesuai ketentuan yakni 5\% (dilansir dari kontan.co.id, 2019).

Semakin tinggi angka NPF semakin tinggi pula tingkat pembiayaan bermasalah pada suatu bank, yang dapat berakibat menurunnya tingkat kesehatan likuiditas bank serta akan berpengaruh pada tingkat kepercayaan para deposan yang menitipkan dananya(Khairunisa, 2020). Tingginya rasio non performing financing (NPF) disebabkan banyaknya pembiayaan non lancar dari kurang lancar sampai macet. Nasabah selaku mudharib kehilangan kemampuan untuk membayar angsuran pokok pembiyaan serta bagi hasil kepada bank selaku sohibul maal, dikarenakan nasabah melakukan penyimpangan atau kelalaian. Dana pembiayaan tidak dimanfaatkan dengan tepat dan tidak sesuai dengan tujuan pembiayaan yang diajukan sebelumnya, ketidakjujuran nasabah dalam melaporkan hasil yang didapatkan sesuai dengan yang seharusnya(Indrianawati et al., 2015).

Setiap bank syariah tentu memiliki prospektif bahwa pembiayaan-pembiayaan yang telah disalurkan akan berjalan lancar dan dapat memberikan sebuah keuntungan pada pihak bank dan nasabah. Namun harapan tersebut tidak selamanya tercapai. Adakalanya pembiayaan yang disalurkan menjadi pembiayaan yang bermasalah sehingga memicu terjadinya kerugian. Oleh karena itu pentingnya penulis untuk mengkaji strategi bank syariah dalam menanggulangi potensi kerugian pada akad mudharabah, yang tak lain bertujuan memberikan solusi yang tepat dalam menangani setiap hal-hal yang memicu terjadinya pembiayaan bermasalah.

Penelitian Agus Surasono yang berjudul Analisis Problem Pembiayaan Mudharabah serta Solusinya. Dari penelitian tersebut disebutkan bahwa pembiayaan bermasalah disebabakan asymmetric information, adverse selection, dan moral hazard. Adanya batasan-batasan untuk mengoptimalkan pembiyaan mudharabah yakni: pemilik modal (sohibul mall) melakukan pengawasan (monitoring), nasabah (mudharib) melakukan pembatasan atas tindakannya (banding), dan keharusan adanya garansi (jaminan) atau agunan fixed asset dan menetapkan rasio maksimal biaya operasional serta pembagian keuntungan berdasarkan profit and loss sharring(Sarono, 2019). 
Penelitian Indrianawati dkk, yang berjudul Manajemen Risiko Pembiayaan Mudharabah pada Perbankan Syariah. Dari penelitian tersebut disebutkan bahwa pembiayaan bermasalah disebabkan oleh side streaming , asymmetric information. Upaya yang dilakukan untuk penyelamatan terhadap pembiayaan bermasalah yaitu dengan rescheduling, recondotioning restructuring, bagi nasabah yang di anggap masih memiliki niat untuk membayar. Jika sebaliknya, dilakukan eksekusi jaminan(Indrianawati et al., 2015).

Berdasarkan penelitian diatas ditemukan penyebab pemicu pembiayaan bermasalah yakni side streaming, asymmetric information, adverse selection, dan moral hazard. penanganannya dengan adanya pengawasan dari shohibul mall, melakukan rescheduling, reconditioning restructuring, bagi nasabah yang dianggap masih memiliki niat untuk membayar. Dan jalan terakhir dilakukan eksekusi jaminan. Perbedaan dengan penelitian saya adalah strategi yang akan saya gunakan yakni pengenalan pra nasabah dan pendampingan pasca nasabah sebelum melakukan rescheduling, reconditioning restructuring dan pemutusan hubungan denga nasabah untuk menanggulangi potensi kerugian pada akad mudharabah.

\section{LANDASAN TEORI}

\subsection{Bank Syariah}

Bank Syariah merupakan bank yang tidak memiliki konsep bunga seperti pada bank konvensional. Pada Bank Syariah, prinsip yang digunakan adalah bagi hasil. Perbankan syariah ini semakin eksis setelah diakui oleh pemerintah dengan lahirnya UndangUndang No. 21 Tahun 2008 yang mengatur secara khusus tentang perbankan syariah. Salah satu tugas dari bank syariah adalah memberikan pembiayaan kepada masyarakat(Edriyanti et al., 2020).

Fungsi bank syariah sama seperti bank pada umumnya yakni sebagai penyalur dan penerima dana masayarakat. Menurut Deddy fungsi bank tidak hanya sebatas menghimpun dan menyalurkan dana, bank juga berperan aktif dalam memberikan motivasi dan mendorong timbulnya motivasi dalam berbagai kegiatan ekonomi (Junaedi, 2020).

\subsection{Mudharabah}

Mudharabah adalah suatu akad kerja sama antara pihak pertama (sohibul maal) penyedia modal dan pihak kedua pengelola atau pekerja (mudharib), keuntungannya akan dibagi sesuai kesepakatan dalam akad, sedangkan apabila terjadi kerugian maka pihak pertama yang akan menanggung kerugian tersebut kecuali adanya kesalahan dari pihak pertama yang menjadi penyebab kerugian(Turmudi, 2016).

Kesimpulannya akad mudharanbah ialah suatu akad pengkongsian dimana bank menjadi pemlilik modal dan nasabah menjadi pengelola atau pekerja. Dalam prakteknya nasabah akan melakukan pengajuan pembiayaan untuk modal usaha kepada bank, kemudian bank akan melakukan penyeleksian terhadap pengajuan pembiayaan nasabah, apabila telah disetujui maka bank dan nasabah akan melakukan perjanjian nisbah bagi hasil dan beberapa perjanjian lainnya terkait dengan akad mudharabah, selanjutnya bank akan menyertakan modal kepada nasabah untuk dikelola, dan nasabah bertugas mengelola dana untuk sebuah usaha serta memberikan bagi hasil dari hasil usaha yang dikelola. 


\subsection{Risiko Pembiayaan}

Risiko pembiayaan merupakan salah satu risiko yang terjadi pada bank. Risiko pembiyaan disebabkan karena adanya ketidakmampuan nasabah untuk memenuhi perjanjian dan atau kewajiban kepada bank sehingga mengakibatkan terjadinya pembiayaan bermasalah. Pembiayaan bermaslaah adalah ketimampuan debitur dalam memenuhi sebagian atau seluruh kewajiban kepada bank sebagaimana yang tertuang dalam kontrak perjanjian(Destiana, 2016).

\section{METODOLOGI PENELITIAN}

Dalam penelitian ini, penulis menggunakan jenis pendekatan library reserch kualitatuf deskriptif. Teknik pengambilan data menggunakan teknik analisis referensional serta melakukan wawancara. Sehubungan dengan hal tersebut penelitian ini mengkaji judul yang di tulis dengan kajian pustaka atau teori yang sumbernya di ambil dari buku-buku yang berkaitan dengan judul yang di kaji saat ini yang kemudian memperoleh hasil yang telah di tulis, serta melakukan wawancara kepada salah satu bank syariah. Tujuan dari penelitian ini adalah untuk meminimalisir pembiayaan bermasalah dengan mengetahui hal-hal yang berpotensi memicu kerugian pada akad mudharabah serta penanggulangannya.

\section{HASIL PENELITIAN}

\subsection{Konseptual Akad Mudharabah dalam Pandanganan Syariat}

Penduduk Hijaz menyebut mudharabah dengan istilah qiradh. Qiradh menurut bahasa diambil dari kata al-qardhu yang memiliki al-qath'u (potongan) sebab pemilik harta memberikan potongan hartanya kepada pengusaha untuk dikelola. Dari hasil usaha itu, pengusaha memberikan potongan keuntungan kepada pemilik harta. Mudahrabah juga bisa diambil dari kata muqarradah yang berarti al musawah (kesamaan) sebab pemilik modal dan pengusaha memiliki hak yang sama terhadap keuntungan (Syafe'i, 2004). Jumlah keuntungan akan dibagikan kepada masing-masing pihak sesuai dengan nisbah yang telah disepakati(Khoerulloh, 2019).

Secara bahasa mudharabah berasal dari kata dharb, yang berarti memukul atau berjalan. Pengertian memukul atau berjalan ini memiliki arti proses seseorang menggerakkan kakinya dalam menjalankan usaha(Mulyaningsih \& Fakhruddin, 2016). Mudharabah adalah suatu akad kerja sama anatara pemilik dana dengan pengelola untuk melakukan suatu kegiatan usaha, nisbah bagi hasil dibagi menurut kesepakatan kedua belah pihak pada saat mengadakan akad. Sedangkan bila terjadi kerugian maka akan ditanggung oleh pengelola dana kecuali, disebabkan oleh kesalahan, kelalaian pengelola dana maka pengelola harus bertanggung jawab atas kerugian tersebut(Nurhayati, 2009).

Menurut Eka jati rahayu, Mudharabah adalah jenis khusus kemitraan dimana salah satu pihak memberikan uang kepada orang lain untuk berinvestasi di perusahaan komersial. Investasi berasal dari mitra pertama yang disebut rabb al-mal, sedangkan bekerja dan pengelolaan adalah tanggung jawab eksklusif yang lain, yang disebut mudharib. Mudharabah juga merupakan pernyataan yang mengandung pengertian bahwa seseorang memberi modal niaga kepada orang lain agar modal itu diniagakan dengan perjanjian keuntungannya dibagi antara dua belah pihak sesuai kesepakatan.

Mudharabah merupakan akad yang telah dikenal oleh umat islam sejak zaman Nabi Muhammad. Dalam hal ini Nabi Muhammad telah mempraktekan sendiri yakni ketika Nabi beranjak dewasa, beliau mulai berdagang di kota Mekah. Beliau berdagang dengan menggunakan modal orang lain, salah satunya dari siti khadijah. Dalam hal ini Siti 
Khodijah menjadi sohibul maal dan Nabi Muhammad sebagai mudharib. Dengan demikian ditinjau dari segi hukum islam, maka praktek mudharabah diperbolehkan, baik menurut Al-quran, Hadist maupun Ijma'(Amalia, 2016).

Adapun landasan hukum mudharabah di dalam Al-quran firman Allah QS. Muzammil: 20

$$
\text { واخرون يضربون فن الارض يبتغون من فضل الله..... }
$$

Artinya: "dan dari orang-orang yang berjalan di muka bumi memcari sebagian karunia Allah SWT.(QS. Muzammil [73]:20)

Landasan hukum mudharabah pada hadis Nabi Muhammad saw: "Abas bin Abdul Muthalib menyerahkan harta sebagai mudharabah, ia menyarankan mudharabahnya agar tidak mengarungi lautan dan menuruni lembah, serta tidak membeli hewan ternak. Jika persyaratan itu dilanggar ia harus menanggung risiko. Ketika persyaratan yang ditetapkan Abas itu di dengar Rasulullah saw. beliau membenarkan." Hadist yang diriwayatkan oleh Ibnu Majah dari Suhaib r.a bahwa Rasulullah saw bersabda "Ada tiga perkara yang diberkahi: jual beli yang ditangguhkan, memberi modal, dan mencampur gandum dengan jelai untuk keluarga, bukan untuk dijual(Lubis, 2016).

Sedangkan menurut ijma' para ulama' tentang bolehnya mudharabah. Diriwayatkan sejumlah sahabat melakukan mudharabah dengan menggunakan harta anak yatim sebagai modal dan tak seorangpun dari mereka menyanggah atau menolak. Jika praktik sahabat dalam suatu praktik amalan tertentu yang disaksikan para sahabat yang lain tidak ada satu pun yang menyanggah, maka hal itu merupakan ijma'. Ketentuan ijma' ini secara sharih mengakui kebenaran praktik pembiayaan mudharabah dalam sebuah perniagaan. Berdasarkan dalil tersebut diketahui bahwa para sahabat telah berkonsensus terhadap letimigasi pengolahan harta anak yatim secara mudharabah(Arifin, 2018).

\subsection{Pra-Pasca Nasabah dan Kausalitasnya}

Pengenalan pra-nasabah merupakan hal wajib yang dilakukan oleh bank dalam melakukan penilaian permohonan pembiayaan bank syariah. Hal ini dilakukan oleh bagian marketing dengan menggunakan prinsip penilaian calon nasabah, antara lain(Lubis, 2016):

1. Character yaitu penilaian bank terhadap karakter atau kepribadian calon penerima pembiayaan. Penilaian ini dilakukan untuk memperkirakan kemungkinan bahwa penerima pembiayaan dapat memenuhi kewajibannya dan tidak akan menyulitkan bank dikemudian hari.

2. Capacity yaitu penilaian secara subyektif tentang kemampuan penerima pembiayaan untuk melakukan pembayaran. Hal ini ditinjau dari pekerjaan, gaji atau laporan penghasilan usaha.

3. Capital yaitu penilaian bank terhadap calon penerima pembiayaan mengenai pengeluaran dan pemasukan calon nasabah pembiayaan, yang bertujuan untuk melihat apakah posisi keuangan calon nasabah secara keseluruhan, baik dimasa lalu maupun proyeksi masa depan mampu dalam menunjang pembiayaan usaha atau proyek calon nasabah yang bersangkutan.

4. Collateral yaitu penilaian jaminan yang dimiliki calon penerima pembiayaan, dimana nilai jaminan harus lebih tinggi dari pembiayaan yang diajukan. Penilaian ini bertujuan 
untuk lebih meyakinkan bahwa jika suatu saat terjadi risiko kegagalan pembayaran, maka jaminan dapat digunakan sebagai kompensasi dari kewajiban.

5. Condition of economic penilaian bank atas kondisi pasar dalam negeri, baik masa lalu maupun masa yang akan datang, sehingga dapat diketahui prospek pemasaran dari hasil usaha debitur yang dibiayai bank, apakah usaha tersebut akan berjalan lancar atau tidak.

6. Syariah penilaian bank terhadap jenis usaha yang dilakukan oleh penerima pembiayaan, hal ini dilakukan untuk memastikan bahwa pembiyaan yang akan dibiayai bank bukan termasuk usaha yang dilarang oleh syariat islam, sesuai dengan fatwa DSN "pengelola tidak boleh menyalahi hukum syariah islam dalam tindakannya yang berhubungan dengan mudharabah".

Penilaian karakter tidak cukup hanya melalui wawancara langsung kepada calon nasabah, adanya survei lapangan sangat diperlukan untuk memastikan kevalidan data calon nasabah. survei lapangan dilakukan dengan cara melakukan wawancara kepada tetangga sekitar yang mencakup radius 40 meter dari rumah calon nasabah, karena jika melakukan wawancara kepada tetangga yang tepat berada disebelah rumah nasabah dikhawatirkan adanya kerja sama antar calon nasabah dengan tetangga tersebut dalam memberikan pernyataan.

Setelah melewati beberapa penilaian karakter calon nasabah. Calon nasabah yang dianggap baik sesuai dengan kriteria prinsip calon nasabah serta memenuhi syarat yuridis permohonan pembiayaan suatu bank, calon nasabah akan diterima menjadi nasabah pembiyaan dalam suatu bank. Monitoring pasca-nasabah dilakukan bank untuk mengawasi dana yang dikelola nasabah berjalan dengan baik atau tidak. salah satu metode pengawasan yang dilakukan Bank Muamalat Indonesia adalah dengan melakukan program kunjungan berkala (periode call) ke lokasi usaha mudharib minimal tiga bulan sekali untuk memantau perkembangan usaha mudharib, meminta laporan bulanan dari pihak mudharib, laporan kunjungan harus dibuat dan diedarkan kepada manajemen (Lestari \& Wati, 2018).

Pengawasan nasabah bisa juga dilakukan dengan silaturrahmi dan menjaga keakraban dengan nasabah. Contoh : seperti yang dilakukan BNI Syariah Probolinggo (Yopie,2020) dengan sering melakukan kunjungan sekedar mampir untuk istirahat dan berbincang-bincang di rumah nasabah supaya tetap terjaga keakraban secara emosional sehingga mempermudah untuk melakukan pemantauan usaha nasabah. berbeda dengan yang dilakukan oleh Kop Wan BMT An Nisa', yakni dengan mengadakan pengajian rutin yang diikuti oleh seluruh anggota yang tempatnya digilir dari satu wilayah ke wilayah lain. Dengan diadakannya pengajian tersebut selain menambah keilmuan juga sekaligus pengontrolan anggota sehingga ada beban tersendiri ketika menunggak bayar pembiayaan terlalu lama(Kamal, 2016).

Selektivitas dalam pemilihan calon nasabah dan melakukan monitoring nasabah guna memilimalisir terjadinya risiko pembiayaan, mengingat relatif tingginya risiko pembiyaan yang terjadi pada akad mudharabah anatara lain side streaming nasabah menggunakan dana bukan seperti yang disebut dalam kontrak, lalai dan melakukan kesalahan yang disengaja, ansymetric information problem perbedaan informasi yang diperoleh pihak bank dan nasabah, dalam hal ini nasabah lebih mengetahui perkembangan usaha yang dijalankan, sehingga kecenderungan salah satu pihak yang menguasai informasi lebih banyak untuk bersikap tidak jujur, yakni nasabah melaksukan penyembunyian keuntungan atau melakukan penyimpangan lainnya(Sarono, 2019). 


\subsection{Perbankan Syariah dan Strateginya dalam Penanggulangan Masalah pada Akad Mudharabah}

Pembiayaan bermasalah adalah pembiayaan yang berdasarkan kualitas nasabahnya tidak mampu menepati jadwal pembayaran angsuran bagi hasil, serta melunasi pembiayaannya. Kolektabilitas pembiyaan digolongkan menjadi lima yakni; lancar, dalam perhatian khusus, kurang lancar, diragukan dan macet, berikut penjelasannya (Ibrahim \& Rahmati, 2017):

1. lancar, pembiayaan dikategorikan lancar apabila pembayaran angsuran pokok dan margin pembiayaan dilakukan tepat waktu, tidak adanya tunggakan, sesuai pada persyaratan akad, penyampaian laporan keuangan selalu dilakukan dengan secara teratur dan akurat, serta dokumentasi perjanjian piutang lengkap dan pengikatan agunan kuat.

2. dalam perhatian khusus, pembiayaan dikategorikan dalam perhatian khusus apabila terdapat tunggakan pembayaran angsuran pokok atau margin sampai dengan 90 hari. Namun dalam penyampaian laporan keuangan selalu dilakukan dengan secara teratur dan akurat, dokumentasi perjanjian piutang lengkap dan pengikatan agunan kuat, serta adanya pelanggaran terhadap persyaratan perjanjian piutang yang tidak prinsipiil.

3. kurang lancar, pembiayaan dikategorikan kurang lancar apabila terdapat tunggakan pembiayaan angsuran pokok atau margin yang telah melewati 90 hari sampai 180 hari, penyampaian laporan keuangan dilakukan secara tidak teratur dan meragukan, dokumentasi perjanjian piutang kurang lengkap dan pengikat agunan kuat, serta terjadi pelanggaran terhadap persyaratan pokok perjanjian piutang, dan berusaha melakukan perpanjangan piutang untuk menyembunyikan kesulitan keuangan.

4. diragukan, pembiayaan dikategorikan diragukan apabila terjadi tunggakan pembiayaan angsuran pokok atau margin yang telah melewati 180 hari sampai 270 hari, nasabah tidak melakukan penyampaian informasi keuangan atau tidak dapat dipercaya, dokumentasi perjanjian piutang tidak lengkap dan pengikatan agunan lemah serta terjadi pelanggaran pada persyaratan pokok perjanjian.

5. Macet, pembiayaan dikategorikan macet apabila terjadi tunggakan pembayaran angsuran pokok atau margin yang telah melewati 270 hari, serta dokumentasi perjanjian piutang dan pengikatan agunan tidak ada.

Pembiayaan dikategorikan bermasalah apabila sudah masuk kategori kolektibilitas kurang lancar, diragukan dan macet. Bila mana terjadi pembiayaan bermasalah maka bank syariah akan melakukan upaya untuk menangani pembiayaan bermasalah tersebut, agar dana yang telah disalurkan oleh bank syariah dapat diterima kembali (Pasal 8 Peraturan Bank Indonesia Nomor 13/3/PBI/2011).

Apabila pemilihan calon nasabah dan monitoring nasabah telah diterapkan, namun masih terjadi pembiayaan bermasalah, maka bank dapat menerapkan strategi-strategi penanganan tehadap pembiayaan bermasalah. Adapun strategi pembiyaan bermasalah dapat dikelompokkan menjadi dua macam yakni stay strategy dan phease out strategy. Stay strategi dilakukan saat bank masih ingin mempertahankan hubungan bisnis dengan nasabah dalam waktu jangka panjang, sementara phease out strategy dilakukan ketika bank tidak ingin melanjutkan hubungan bisinis dengan nasabah dalam waktu yang panjang(NURJANAH, 2016).

Stay strategi dilakukan apabila nasabah memenuhi beberapa kriteria seperti; kesulitan yang dihadapi usaha nasabah bersifat sementara, nasabah dinilai kooperatif dan 
masih memiliki prospek usaha. Stay strategi ini dilaksanakan dengan menggunakan upaya-upaya restrukturisasi (rescheduling, reconditioning, dan restructuring) (Zulfikri et al., 2019). Rescheduling penjadwalan kembali pelunasan, bank memberikan kelonggaran kepada mudharib dalam masalah jangka waktu angsuran untuk pengembalian modal kerja yang telah jatuh tempo, misalnya jangka waktu pembayaran dari 6 bulan menjadi satu tahun sehingga mudharib mempunyai waktu yang lebih lama untuk mengembalikannya. Upaya penyehatan dengan penjadwalan kembali pengembalian modal kerja dilakukan apabila mudharib memang tidak bisa mengembalikan tepat pada waktu jatuh tempo. Reconditioning perubahan sebagian atau seluruh persyaratan pembiaayaan, bank memberikan keringanan bagi hasil kepada mudharib dengan cara mengurangi nisbah bagi hasil yang seharusnya diterima. Hal ini diberikan apabila mudharib belum bisa mengembalikan modal kerja, karena kondisi usaha yang menurun. Restructuring perubahan persyaratan pembiayaan, tidak terbatas pada rescheduling dan reconditioning. Pada hal ini bank memberikan fasilitas penambahan pembiayaan kembali kepada anggota yang mengalami masalah dalam usahanya yang disebabkan diluar kemampuan anggota, seperti usaha terkena musibah, karena faktor alam dan lain sebagainya. Dalam penataan kembali persyaratan ini, isi perjanjian mudharabah ditata kembali bisa ditambahi atau dikurangi bila perlu(Kamal, 2016).

Apabila restrukturisasi pembiayaan dilakukan secara menyeluruh atau restrukturasi pembiayaan dilakukan melalui konversi akad, maka harus dibuat akad pembiayaan baru. Dalam hal ini, pihak nasabah juga dikenakan ketentuan dan pembiayaan administrasi sebagaimana layaknya pembuatan akad pembiayaan baru. Hal ini disebabkan karena restrukturasi yang dilakukan tidak sebatas klausul tertentu saja seperti halnya addendum, tetapi mengganti akad atau mengkonverensi akad yang dibuat sebelumnya dengan yang baru.(Asmara et al., 2015).

Phease out strategy digunakan apabila nasabah dinilai sudah prospek usaha dan nasabah tidak cooperatif untuk menyelesaikan pembiayaa. pada strategi ini bank melakukan dua macam pendekatan yakni soft approach dan hard approach. Soft approach merupakan pendekatan yang identik dengan upaya penyelesaian pembiayaan bermasalah di luar pengadilan. pada strategi ini bank melaksanakan langkah-langkah berupa restructuring, recondictioning, rescheduling yang relative sama diterapkan pada stay strategy, namun bedanya pada strategi ini bank tidak berkeinginan untuk menjalin hubungan jangaka waktu yang panjang dengan mudharib. Sementara hard approach dilakukan apabila soft approach tidak bisa menyelesaikan pembiayaan bermasalah yang terjadi, maka selanjutnya akan ditempuh cara hard appoarch yakni penyelesaian pembiayaan bermasalah dengan cara melibatkan jalur hukum(Musdalifah \& Rahim, 2020). Cara ini merupakan opsi paling terakhir yang dilakukan oleh pihak bank apabila nasabah sudah tidak bisa diajak bermusyawarah secara kekeluargaan atau tidak memiliki etikad baik, maka penyelesaian pembiayaan dilakukan melalui penyerahan agunan/aset atau litigasi yang berupa eksekusi objek jaminan melalui pihak manajemen bank, pengadilan, maupun melalui Badan Abitrase Syariah Nasional (BASYARNAS)(Zulfikri et al., 2019).

Berdasarkan strategi-strategi diatas, maka dapat dilakukan penanganan yang tepat pada pembiayaan sesuai dengan tingkat kolektibilitasnya, yakni antara lain(Harahap \& Pratama, 2019):

1. Pembiayaan dalam kategori lancar dapat dilakukan dengan melakukan pemantauan usaha nasabah, melakukan pembinaan terhadap anggota dengan melalui latihanlatihan. 
2. Pembiayaan dalam kategori perhatian khusus yakni pembiayaan yang berpotensi bermasalah dapat dilakukan dengan cara melakukan pembinaan terhadap anggota, memberi Surat Peringatan 1 (SP1), melakukan kunjungan atau silaturrahmi kepada nasabah oleh bagian pembiayaan, serta melakukan upaya preventif melalui rescheduling jadwal angsuran dan juga dapat dilakuakn reconditioning.

3. Pembiayaan dalam kategori kurang lancar dapat dilakukan dengan memberi Surat Peringatan 2 (SP2), melakukan kunjungan atau silaturrahmi kepada nasabah dengan lebih bersungguh-sungguh oleh bagian pembiayaan, melakukan upaya penyehatan dengan melakukan rescheduling dan reconditioning.

4. Pembiayaan dalam kategori diragukan dan macet dapat dilakukan dengan cara memberi Surat Peringatan 3 (SP3), melakukan restrukturisasi pembiayaan yakni melalui rescheduling, reconditioning dan restructuring, akan tetapi apabila masih tidak terselesaikan maka bank akan melakukan pemberitahuan mengenai pelelangan jaminan kepada nasabah. namun apabila nasabah tidak bisa diajak bermusyawarah maka bank akan melakukan opsi terakhir melalui jalur hukum.

\section{KESIMPULAN}

Pembiayaan bermasalah merupakan salah satu risiko pembiayaan yang sering terjadi pada akad mudharabah. Pembiayaan bermasalah disebabkan adanya side streaming nasabah menggunakan dana bukan seperti yang disebutkan dalam kontrak, lalai dan melakukan kesalahan yang disengaja, ansymetric information problem kecenderungan salah satu pihak yang menguasai informasi lebih banyak untuk bersikap tidak jujur yakni nasabah melakukan penyembunyian keuntungan. Dalam hal ini selektivitas dalam pemilihan calon nasabah dan melakukan monitoring nasabah sangat penting dilakukan oleh bank guna memilimalisir terjadinya risiko pembiayaan yakni dengan melakukan pengenalan nasabah melalui penilaian karakter dengan menggunakan prinsip $5 \mathrm{C}+1 \mathrm{~S}$; Character, Capacity, Capital,Collateral, Condition of Economic dan Syariah. Monitoring nasabah dengan selalu menjaga tali silaturrahmi dengan, melakukan program kunjungan berkala (periode call) ke lokasi usaha nasabah minimal tiga bulan sekali untuk memantau perkembangan usaha nasabah, meminta laporan bulanan dari pihak nasabah mengenai usahanya, laporan kunjungan harus dibuat dan diedarkan kepada manajemen. Untuk menangani pembiayan bermasalah terdapat dua strategi yakni pertama melanjutkan hubungan dengan nasabah (stay strategy) dengan melakukan restrukturisasi pembiayaan (rescheduling, restructuring, reconditioning). Kedua memutuskan hubungan dengan nasabah (phease out strategy). Strategi ini dilakukan menggunakan dua pendekatan yakni soft approach penyelesaian pembiayaan diluar pengadilan dengan cara melakukan rekstrukturasi pembiyaan dalam konteks tidak ingin melanjutkan hubungan dengan nasabah. Hard approah penyelesaian pembiayaan dengan cara melibatkan jalur hukum melalui penyerahan agunan/aset atau litigasi yang berupa eksekusi objek jaminan melalui pihak manajemen bank, pengadilan, maupun melalui Badan Abitrase Syariah Nasional (BASYARNAS).

\section{DAFTAR PUSTAKA}

Amalia, N. (2016). Struktur Pembiayaan dan Pengaruhnya Terhadap Profitabilitas Bank Muamalat Indonesia Dan Bank Syariah Mandiri. Jurnal Ilmu Dan Riset Akuntansi (JIRA), 5(5).

Arifin, S. (2018). Strategi Perbankan Syariah Dalam Menghadapi Pembiayaan Dengan Akad Mudharabah Yang Bermasalah (Studi di Bri Syariah Pamekasan). Jurnal 
Justisia Ekonomika: Magister Hukum Ekonomi Syariah, 2(1).

Asmara, J., Ali, D., \& Jauhari, I. (2015). Proses Penyelesaian Pembiayaan Bermasalah Melalui Restrukturisasi (Suatu Penelitian Pada Bank Syariah Mandiri Cabang Pembantu Jantho). Jurnal Ilmu Hukum, 3(3).

Destiana, R. (2016). Analisis Dana Pihak Ketiga dan Risiko Terhadap Pembiayaan Mudharabah dan Musyarakah Pada Bank Syariah di Indonesia. LOGIKA Jurnal Ilmiah Lemlit Unswagati Cirebon, 17(2), 42-54.

Edriyanti, R., Khairunnisa, A. (2020). Analisis Pengaruh Pembiayaan Mudharabah, Musyarakah, Murabahah (Studi Kasus Bprs Di Indonesia). NISBAH Jurnal Perbankan Syari'ah, 6(2), 63-74.

Harahap, H., \& Pratama, M. A. (2019). Analysis Of Factors Affecting The Amount Of Mudharabah Deposit. NISBAH Jurnal Perbankan Syari'ah 6(2), 116-123.

Ibrahim, A., \& Rahmati, A. (2017). Analisis Solutif Penyelesaian Pembiayaan Bermasalah Di Bank Syariah: Kajian Pada Produk Murabahah Di Bank Muamalat Indonesia Banda Aceh. Iqtishadia: Jurnal Kajian Ekonomi Dan Bisnis Islam STAIN Kudus, 10(1), 71-96.

Indrianawati, I., Lailah, N., \& Karina, D. (2015). Manajemen Risiko Pembiayaan Mudharabah Pada Perbankan Syariah. Journal of Innovation in Business and Economics, 6(1), 55-66.

Junaedi, D. (2020). Pengaruh Pelayanan Prima Terhadap Kepuasan Nasabah (Studi Kasus Di PT. Bank Jatim Capem Maron Probolinggo). PROFIT: Jurnal Kajian Ekonomi Dan Perbankan Syariah, 4(1), 24-32.

Kamal, M. (2016). Kebijakan Penanganan Pembiayaan Muḍārabah Bermasalah Pada Kopwan Bmt An-Nisa'yogyakarta. Jurnal Syari'ah, 5(1).

Khairunisa, M. (2020). Penyelesaian Pembiayaan Bermasalah Pada Bank Syariah. Jurnal Islamic business and finance, $1(1)$.

Khoerulloh, A. K. (2019). Pengaruh Pendapatan Bagi Hasil Mudharabah dan Pendapatan Margin Murabahah Terhadap Laba Usaha pada BMT Muda Surabaya. Maro: Jurnal Ekonomi Syariah Dan Bisnis, 2(1), 38-54.

Lestari, N. M., \& Wati, S. (2018). Strategi Penyelesaian Pembiayaan Bermasalah Pada Akad Mudharabah Di Bank Muamalat Indonesia Serta Pengaruhnya Terhadap Penurunan Tingkat Non Performing Financing (NPF) Bank Muamalat Indonesia. Jurnal Ekonomi Islam, 9(1), 75-99.

Lubis, A. (2016). Agency Problem Dalam Penerapan Pembiayaan Akad Mudharabah Pada Perbankan Syariah. Alqalam, 33(1), 46.

Mulyaningsih, S., \& Fakhruddin, I. (2016). Pengaruh Non Performing Financing Pembiayaan Mudharabah dan Non Performing Financing Pembiayaan Musyarakah terhadap Profitabilitas pada Bank Umum Syariah di Indonesia. Jurnal Media Ekonomi, 16(1).

Musdalifah, M., \& Rahim, A. (2020). Strategi Penyelesaian Pembiayaan Bermasalah Untuk Mencegah Financial Distress Pada Bank Syariah Mandiri (BSM) Cab. Bone. Jurnal Ilmiah Al-Tsarwah: Ilmu Ekonomi Dan Keuangan (Konvensional Dan Syariah), 3(1), 43-72.

Nurjanah, M. (2016). Strategi Penyelamatan Pembiayaan Bermasalah Pada Pembiayaan Murabahah Di Bank Syariah Mandiri Cabang Purwokerto. IAIN Purwokerto.

Sarono, A. (2019). Analisis Problem Pembiayaan Mudharabah Serta Solusinya. Diponegoro Private Law Review, 4(1).

Turmudi, M. (2016). Manajemen Penyelesaian Pembiayaan Bermasalah Pada Lembaga 
Perbankan Syariah. Li Falah: Jurnal Studi Ekonomi Dan Bisnis Islam, 1(1), 95106.]

Wawancara dengan Yopie Rama Yuarsyah sebagai salah satu karyawan bagian marketing Bank BNI Syariah Kantor Cabang Problinggo.

Zulfikri, A., Sobari, A., \& Gustiawati, S. (2019). Strategi Penyelamatan Pembiayaan Bermasalah Pada Pembiayaan Murabahah Bank BNI Syariah Cabang Bogor. Al Maal: Journal of Islamic Economics and Banking, 1(1), 65-78. 